\title{
Russian-Speaking Digital Buddhism: Neither Cyber, nor Sangha
}

\author{
Elena Ostrovskaya ${ }^{1} \mathbb{D}$, Timur Badmatsyrenov ${ }^{2, *} \mathbb{D}$, Fyodor Khandarov ${ }^{3}$ and Innokentii Aktamov ${ }^{4}$
}

1 Faculty of Sociology, Saint Petersburg State University, 199034 St Petersburg, Russia; e.ostrovskaya@spbu.ru 2 Department of Politology and Sociology, Dorzhi Banzarov Buryat State University, 670000 Ulan-Ude, Russia

3 Laboratory of Digital Economics, Institute of Economics and Management, Dorzhi Banzarov Buryat State University, 670000 Ulan-Ude, Russia; fedor.khandarov@gmail.com

4 Laboratory "Oriental Languages Translations Center", Institute for Mongolian, Buddhist and Tibetan Studies of the Siberian Branch of the Russian Academy of Sciences, 670047 Ulan-Ude, Russia; aktamov13@gmail.com

* Correspondence: batorovitch@mail.ru

Citation: Badmatsyrenov, Timur, Elena Ostrovskaya, Fyodor Khandarov, and Innokentii Aktamov. 2021. Russian-Speaking Digital Buddhism: Neither Cyber, nor Sangha. Religions 12: 449. https://doi.org/ 10.3390/rel12060449

\section{Academic Editors: Svetlana}

Sharonova, Marta Soler-Gallart and Andy Rotman

\section{Received: 14 May 2021}

Accepted: 10 June 2021

Published: 17 June 2021

Publisher's Note: MDPI stays neutral with regard to jurisdictional claims in published maps and institutional affiliations.

Copyright: (C) 2021 by the authors. Licensee MDPI, Basel, Switzerland. This article is an open access article distributed under the terms and conditions of the Creative Commons Attribution (CC BY) license (https:// creativecommons.org/licenses/by/ $4.0 /)$.

\begin{abstract}
The paper presents the results of a study that implemented a mixed methods approach to explore the question of correlation between online and offline activities of Buddhist organizations and communities in Russia. The research was carried out in 2019-2020 and addressed the following key issues: How do Buddhist websites and social media communities actually interact with offline organizations and Russian-speaking Buddhist communities? How do the ideological specifics of Buddhist organizations and communities influence their negotiations with the Internet and strategies towards new media technologies? Within the methodological frame of the religious-social shaping of technology approach by Heidi Campbell, we used the typology of religious digital creatives to reveal the strategies created by the Russian-speaking Buddhist communities developing their own identity, authority, and boundaries by means of digital technologies. In the first stage, we used quantitative software non-reactive methods to collect data from social media with the application of mathematical modeling techniques to build a graph model of Buddhist online communities in the vk.com social network and identify and describe its clusters. The second stage of the research combined biographical narratives of Buddhist digital creatives and expert interviews.
\end{abstract}

Keywords: Russian-speaking digital Buddhism; Buddhist online communities; Buddhist digital creatives; International Dzogchen Community; the Russian-speaking Theravada

\section{Introduction}

In the Russian sociology of religion, digital Buddhism is a relatively new object of study. In the past decade, a number of articles devoted to the common features of the Russian-speaking Buddhists' Internet (Dondukov 2017, 2019), websites, electronic resources, and some Buddhist communities of the vk.com social media were published (Aktamov et al. 2015, pp. 125-30; Aktamov et al. 2018, pp. 100-5). Their methodological part usually provides Heidi Campbell's typology, which identifies three waves of research related to the academic study of religion and the Internet and contains references to "cybersangha" by Charles Prebish ${ }^{1}$ or "online religion and religion online" by Christopher Helland $^{2}$. Their practical part includes a brief review of Buddhist websites, some accounts on social networks, or a description of some kind of "virtual Buddhism" on the Russian Internet. Following the logic of Prebish and Helland's concepts, the Russian studies of digital Buddhism do not raise the question of the interrelation of Buddhist websites, social media accounts, and online forums with the practice of offline Buddhist communities and organizations. No questions are raised about the relevance of the described sites, forums, accounts, and applications among real Buddhist communities and organizations in Russia. Moreover, some publications reveal theses about the alleged cyber manifestations 
of offline confrontation between traditional Buddhism and neophyte Buddhism (Dorzhigushaeva and Dondukov 2016). However, these authors do not support their theses with field research.

In 2015-2018, our project group was focused on the mapping of the current Buddhist cyberspace of the Russian Net (Badmatsyrenov et al. 2018). As a result, we reached a question about the real relevance of the discovered websites, platforms, and forums among offline Russian-speaking Buddhist communities ${ }^{3}$. This prompted us to turn to the methodology of the latest studies on digital Buddhism. However, here we came across a controversy. The researchers with Buddhist affiliation insist that it is time to end the discussion about the authenticity of Buddhism on the Internet and to accept online Buddhism as one of the forms of its socio-cultural entrenchment (Veidlinger 2015, pp. 2-3). From this perspective, it is proposed to use the methods of participant observation, virtual ethnography, and case study (Grieve 2015, pp. 23-25; Falcone 2015, pp. 174-75). The object of study in such a methodological framework is, as a rule, Buddhist virtual temples and games, online meditations, and offerings to virtual sacred objects.

Sociological studies on religion and digital media usually underline that Buddhism is a developing area on the Internet that needs to develop adequate tools for its online and offline correlations (Campbell 2010, pp. 190-91; Campbell 2013, p. 13; Cheong et al. 2011, p. 1160; Connelly 2015, p. 58). Sociological studies of online American Buddhism have shown that the majority of users classified as "cybersangha" are actually looking for information about offline communities via the Internet or try to find something for bedtime reading (Tweed 2002). Criticizing the current state of affairs, the researchers propose to revise the concepts of "cybersangha" and "online religion and religion online" by comparing Buddhist digital activity (websites, apps, blogs) with offline belonging to the Buddhist communities (Ostrowski 2015, pp. 191-203; Connelly 2015, pp. 59-60).

Our new research, carried out in 2019-2020, was focused on studying the interaction of the offline and online realities of Russian-speaking Buddhist communities. We have addressed the following key issues: How do Buddhist websites and social media communities actually interact with offline Buddhist organizations and communities? How do the ideological specifics of Buddhist organizations and communities influence their strategies for building relationships with the Internet and new technologies? Is there a reverse impact of media technologies on the boundaries and identity of Russian-speaking Buddhist communities?

\section{Materials and Methods}

This project implemented a mixed methods approach to explore the question of correlation between online and offline activities of Buddhist organizations and communities in Russia. As a methodological frame of reference, we used the approach of religioussocial shaping of technology by Heidi Campbell. We also used the typology of religious digital creatives by Campbell to reveal the strategies created by the Russian-speaking Buddhist communities developing their own identity, authority, and boundaries by means of digital technologies.

Campbell argued that when studying digital media and religion, it is important to consider how the cultural and religious norms inform the adoption, rejection, and negotiation of the new. An algorithm for identifying the factors informing a religious community's responses to new media is a part of the approach designated by Campbell as religious-social shaping of technology media. It involves the following four stages of research: studying the history and traditions of a certain religious community; identifying key religious doctrines and patterns that influence building relationships with the media; establishing the forms of religious communities' digital media usage; and analysis of the discourse of a religious community on new media technologies (Campbell 2010).

Campbell's significant contribution to the methodology for studying the problem of religious-social shaping of technology was the typology of religious digital creatives (Campbell 2016). Based on the conceptual development of John Anderson (Anderson 
1999, pp. 41-55) and the results of her own research on digital Catholicism, Campbell proposed to distinguish three types of religious digital creatives whose activities shape digital religious discourses. They are digital professionals, digital spokespersons, and digital strategists. Digital professionals are religiously motivated developers of software, mobile apps, and websites. They usually have a professional IT education, experience and skills, or a unique talent in this field. They create online profiles of a religious organization and consider their activities as a form of religious service (Campbell 2016, p. 310).

Digital spokespersons are ordinary members of a religious organization hired by it under an employment contract to manage websites, profiles, forums, and public debates on behalf of the organization and to carry out other media activities. They often have to learn technical skills and obtain knowledge of media technology from scratch. They see themselves as representatives of a religious organization for the general public and as translators of the organization's offline religious identity into an online environment (Campbell 2016, p. 312).

Digital strategists are all those who use existing digital tools for a distinct religious agenda. Campbell's notion of digital strategists includes online missionaries who create tools for digital dissemination of doctrines and attitudes of a particular religion and developers of religious mobile apps, websites, and networks. Among these digital strategists, Campbell distinguishes two significant types of bloggers- 'theologians who blog' and 'theoblogians'. The first are religious professionals with a special religious education and a fixed position in the hierocratic hierarchy. The second type of digital strategists'theoblogians' - are all those who create blogs to spread their own reflections on doctrinal topics and thus gain a reputation as theological thinkers. The authority of 'theoblogians' is based on their online writing, rather than religious education or offline status in the religious hierarchy. The network surrounding their blogs makes them globally popular. The digital audience, as a rule, perceives them as public theologians and invests them with a unique charismatic flair (Campbell 2016, p. 315).

The empirical part of our study was carried out from January 2019 to November 2020 and has two stages. At the first stage, we used quantitative software non-reactive methods for collecting data from social media using specially developed software-a crawler data collector. We have developed a list of search queries containing key semantic units (words and phrases) reflecting general Buddhist concepts (Buddha, Dharma, etc.), schools and trends (Gelug, Theravada, Dzogchen, etc.), and forms of Buddhist communities' social organization (sangha, datsan, khurul, etc.). After that, we made a series of requests to vk.com API and obtained a list of more than a thousand communities found by "Buddhist" search queries.

The next step was the application of mathematical modeling techniques. With their help, we built a graph model and identified and described clusters of Buddhist online communities in the vk.com social media. Within the framework of this study, vk.com groups were considered the vertices of the graph. A weighted edge between a pair of vertices indicates the presence of common subscribers in two groups corresponding to the vertices (the more common subscribers, the greater the weight of the edge). In this paper, graph clustering is understood as the problem of partitioning a set of vertices into disjoint subsets in such a way that the density of bonds between the vertices of one subset is higher than between the vertices of different subsets. To carry out clustering, we used the method of optimizing the functional modularity (Martynov et al. 2018). In the context of the accepted structure of the graph, clustering will mean that one cluster will include groups with a higher density of edges between them (there are more edges between them and their total weight is higher), i.e., groups that are similar in composition of users. In this case, the density of bonds between vertices in different clusters will be lower. Thus, graph clustering will split a set of VK groups into clusters that differ in subsets of their users.

One of the key results of the first stage was the so-called sacral map of the Russianspeaking Buddhist online communities of vk.com. The analysis of this map revealed the structure of relationships between those communities. It was also useful to formulate 
questions for the second stage of our research-a selective study of some Buddhist online communities of the vk.com network using qualitative methods of sociological research.

At the second stage, we studied the strategies for using the Internet and media technologies by Russian-speaking representatives of the International Dzogchen Community and Theravada community. The digital infrastructure and practices of these two branches of modern Russophone Buddhism, as well as their community structures, have been understudied. In light of this, we decided to combine biographical narratives and expert interviews. Campbell's typology of digital religious creatives was used to develop a sample of respondents to be interviewed about community negotiations with the Internet and strategies for using new media technologies. In addition, this typology served as an analytical framework for interpreting interview results. In the answers of respondents, we singled out semantic blocks based on their motivation to use digital technologies for religious purposes. We selected the sample in accordance with the following criteria: participation in the creation of a community; productive digital activity for at least five years; a clear profile of online activity; mentioning the account/blog/site of a certain "creative" in more than one interview. All respondents were presented with the same list of questions, which included 2 thematic blocks: the first is biographical and the second concerned the targeted use of media by Buddhist communities of a particular school. The total number of interviews was 21; direct quotes from 7 of them we presented in this paper. The respondents were informed in advance about the records during the conversation and gave their permission. When the text was ready, the respondents had the opportunity to have a look at the sections with the information about them and their quotes. We had obtained permission from each of them to use these citations in the publication.

\section{Results}

Users of vk.com, when filling out their profile in the category "worldview", can choose one of the options proposed by the developers of this social media, or their own option. The proposed options include Judaism, Orthodoxy, Catholicism, Protestantism, Islam, Buddhism, Confucianism, secular humanism, and Rastafarianism.

Below we present the results of queries in the VK search engine in accordance with the list developed by us during the research. We also should note that users of vk.com are faced with a large variety of Buddhist and quasi-Buddhist communities. In Table 1, we have presented the results of queries made in August 2019 for the search units we selected earlier. An analysis of the obtained data allows us to assert that the number of online communities significantly exceeds the number of actually registered offline Buddhist organizations ${ }^{4}$.

We revealed a considerable increase in the number of users who had chosen Buddhism as their worldview. In 2011, there were about 360,000 such profiles, and by August 2019, their number exceeded 600,000 profiles. In our previous research, we found that the Russian-speaking Buddhist environment on vk.com is poorly integrated. Buddhism is not an assortative factor, and Buddhist users are integrated into communities that are weakly related to each other. On the other hand, the dependence of the distribution of the vertices degrees on the power law and the value of the average length of the shortest path (six handshakes rule) testify that the graph of Buddhist vk.com users actually corresponds to the infrastructure of social media. At the same time, it reproduces relatively autonomous sets of ethnic and territorial characteristics of offline users (Badmatsyrenov et al. 2018, pp. 74-82).

A close study of the newly obtained data showed that most of the Buddhist groups had only a few subscribers, and the latest activity on the wall of the group dates back to 2017-2018. Given this, for further analysis, we selected the online Buddhist groups whose subscriber count exceeded 1000 and the pages that showed activity for 2019-2020. Thus, the sample included 119 relatively large communities, which we studied using mathematical modeling. 
Table 1. Number of communities by units of analysis.

\begin{tabular}{|c|c|c|}
\hline No. & Search Query & $\begin{array}{l}\text { Number of } \\
\text { Communities }\end{array}$ \\
\hline 1. & Буддизм/Buddhism & 508 \\
\hline 2. & Будда/Buddha & 309 \\
\hline 3. & Шакьямуни /Shakyamuni & 7 \\
\hline 4. & Buddhism & 19 \\
\hline 5. & Буддийский/Buddhist & 201 \\
\hline 6. & Гелуг/Gelug & 5 \\
\hline 7. & Дзен/Zen & 974 \\
\hline 8. & дзен-буддизм/Zen Buddhism & 45 \\
\hline 9. & Дзэн/Zen & 113 \\
\hline 10. & дзэн-буддизм/Zen Buddhism & 9 \\
\hline 11. & чань-буддизм/Chan Buddhism & 2 \\
\hline 12. & Кван ум/Kwan Um & 10 \\
\hline 13. & Тхеравада/Theravāda & 51 \\
\hline \multirow[t]{2}{*}{14.} & Дзогчен/Dzogchen & 66 \\
\hline & Карма Кагью/буддизмАлмазного & \\
\hline \multirow[t]{2}{*}{15.} & Пути & 90 \\
\hline & Karma Kagyu/Diamond Way Buddhism & \\
\hline \multirow{2}{*}{16.} & тибетский буддизм/буддизм Тибета & 19 \\
\hline & Tibetan Buddhism/Buddhism of Tibet & \\
\hline \multirow[t]{2}{*}{17.} & бурятский буддизм /буддизм Бурятии & 4 \\
\hline & Buryat Buddhism/Buddhism of Buryatia & \\
\hline 18. & русский буддизм/Russian Buddhism & 4 \\
\hline 19. & дацан/Datsan & 90 \\
\hline 20. & хурул/khurul & 11 \\
\hline 21. & хурээ/khuree & 7 \\
\hline 22. & дуган/dugan & 22 \\
\hline 23. & буддийский храм/Buddhist temple & 15 \\
\hline 24. & Далай-лама/Dalai Lama & 36 \\
\hline 25. & Дже Цонкапа/Je Tsongkhapa & 4 \\
\hline 26. & Оле Нидал/Ole Nydahl & 4 \\
\hline & Геше Джампа Тинлей/Geshe Jampa & 2 \\
\hline 27. & Tinley & 2 \\
\hline 28. & Лама/Lama & 694 \\
\hline
\end{tabular}

We have developed a graph model in which 119 Buddhist vk.com groups with more than 1000 subscribers were considered as graph vertices. The weight of undirected edges between vertices is the number of common subscribers of the two groups. The clustering of such a graph based on the analysis of the structure of its bonds should reflect the "kinship" of groups by the composition of users. The social graph used in the work has been developed on the basis of access to vk.com via the API of this social media. It contains information about the networks of group subscribers only with open profile data. Data were collected automatically by means of a specially developed crawler program, a data collector for social media.

Figure 1 presents the results of graph clustering. All communities in it were divided into four clusters and highlighted in green, orange, blue, and lilac. Let us consider each of them in detail.

The green cluster includes 40 groups with a total of 477,189 subscribers. It contains online communities that represent the Russia Gelug Tibetan and Mongolian Buddhist tradition. Most of these online vk.com groups are established by the Buddhists from Buryatia, Tuva, and Kalmykia. The largest one among them is The Precious Teachings of His Holiness the Dalai Lama, 230,000 subscribers (https:/ /vk.com/dalailama14 (accessed on 3 April 2021)). This cluster includes several public pages about the Dalai Lama and his verified profile (https://vk.com/dalailama (accessed on 3 April 2021)). These public pages are linked to the official websites The Office of His Holiness the Dalai Lama, Center for Tibetan Culture and Information, and Honorary Representative of His Holiness the Dalai Lama 
in Russia and Mongolia Telo Tulku Rinpoche" (https:/ /ru.dalailama.com/office/contact (accessed on 3 April 2021)). There was also a network of groups representing the followers of the offline communities, which were organized by Geshe Jampa Tinley in Russia and the near abroad. Another part of this cluster was represented by the communities of datsans in Buryatia, Zabaikalsky Krai, Novosibirsk and Irkutsk Oblasts, as well as khuruls in Kalmykia, khurees in Tuva, and kurees in the Altai Republic.

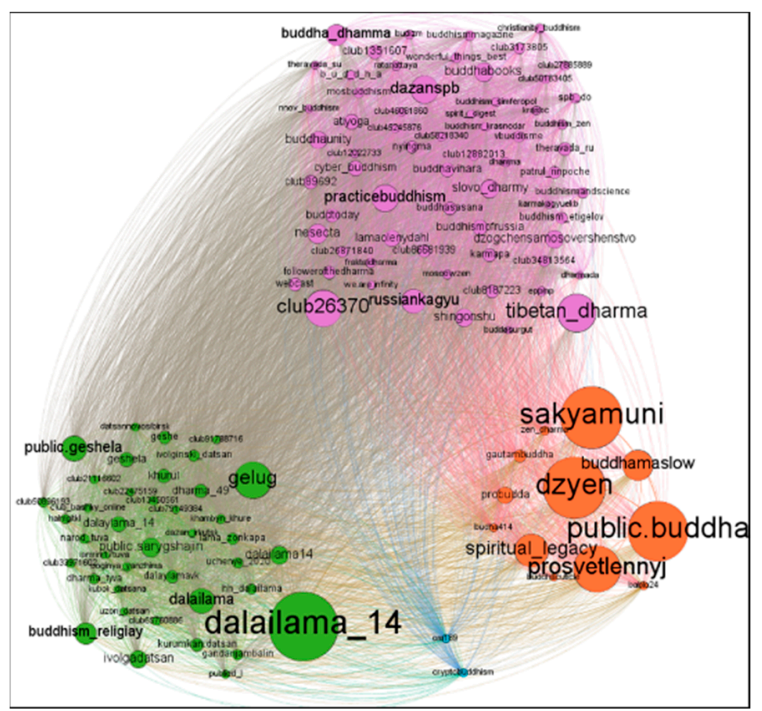

Figure 1. Graph clustering.

The orange cluster covered 11 communities; the total number of their subscribers amounted to more than a million, and the average number was 100,000. Zen Buddhism was the largest community of this cluster ${ }^{5}$. It has 336,093 subscribers. The key forms of online communication here were e-mail updates, news discussions, and comments of subscribers on the topics of moderators' messages. The bulk of the information posted on the community wall is quotes from Zen writings or publications that contain material on Zen. The administrators of this community are professional SMM managers who offer such information for advertising in the group's section "Esoterics. Astrology. Self-Cognition, Yoga". A close text analysis of the thematic content of other Zen communities allows us to assert that they comprised users who sympathize with Buddhism regardless of affiliation to a specific school or ethnocultural form. Only a small part of the communities in this cluster included groups identifying themselves with the South Korean or Japanese alternatives of Zen Buddhism. As a rule, they were focused on collecting and discussing materials thematically devoted to the doctrinal issues of Zen Buddhism, as well as studying Japanese and South Korean culture. However, the digital performing of Zen in Russian-speaking online communities may be a field of separate research.

The blue cluster included two groups-"Buddhism" and "Buddhism I Music | Mantras". The total number of subscribers was 11,136.

The lilac cluster involved 66 groups with a total number of 329,639 subscribers. On average, these groups comprised about 5000 users. The lilac cluster as a whole was characterized by a significant presence of non-ethnic convert Buddhists with a noticeable connection between their online and offline community memberships. The online group St. Petersburg temple Datsan Gunzechoinei, for example, entered this cluster due to the specifics of its location and the policy of regular interaction with communities of different Buddhist traditions. The further analysis of this cluster brought the additional sub-clustering.

The first sub-cluster included groups that were created by offline communities of the Diamond Way Buddhist centers of the Karma Kagyu lineage. As of August 2019, there were 90 of them on vk.com. This is comparable to the number of regional Russian offline 
communities of the Russian Association of Diamond Way Buddhists of the Karma Kagyu Lineage. This association comprised more than 80 communities in all regions of Russia and united several thousand followers under the umbrella of Vajrayana Buddhism of Tibet. All these groups were created by members of offline centers under the spiritual leadership of the 17th Karmapa Trinley Thaye Dorje. They are characterized by the branding of Karma Kagyu name and visual design and have similar content. All this testifies to a relatively high level of integration of online and offline activities of these communities.

The second sub-cluster comprised eight groups with a total of 23,106 subscribers. As in the previous case, online Dzogchen groups in vk.com were created by representatives of regional Russian-speaking offline communities who identify themselves as the International Dzogchen Community. Online Dzogchen groups are mostly closed, and joining them requires making a query and often involves filling out a form with questions about the purpose of subscribing to the group. Based on what we know from the data obtained as a result of quantitative analysis, the subscribers of these communities are connected with each other.

The third sub-cluster is formed of groups created by the followers of Theravada Buddhism. Some of them represent regional offline Russian-speaking communities of various teachers and Theravada traditions. The other ones are created by the developers of the Russian-speaking Theravada websites. The groups of this sub-cluster were poorly integrated in their online activities and had a fixed composition of subscribers. Some of them are closed, so a potential subscriber should apply for participation and fill up a form.

From the panorama considered above, it becomes clear that the Buddhist niche of vk.com involves both digital representatives of the offline organizations of Russophone Buddhism and various quasi-Buddhist communities that have only virtual existence. The discovered clusters make it possible to compile a kind of online map of Russian-speaking Buddhism, where Buryat, Kalmyk, and Tuvan branches of the Gelugpa school, the Russian Association of Communities as a part of the International Karma Kagyu Organization, the Russophone part of the International Dzogchen Community, and the Theravada prevail. At the next stage of studying the Buddhist digital network, we focused on the online communities with a vast number of subscribers found on the vk.com and facebook.com platforms. This kind of community prevailed in the green and lilac clusters. Here we were faced with unexpected results. Thus, the online communities of the green cluster, who identify themselves as traditional Gelug, did not amount to much on the Facebook network. In the three sub-clusters of the "lilac" cluster, Theravada and Dzogchen open and closed groups, public pages, personal blogs, and Theravada website pages prevailed on Facebook. There were no groups, public pages, or blogs belonging to the Russophone branch of the International Karma Kagyu Community.

\section{Discussion}

Guided by the results of the quantitative study phase, we decided to focus on the analysis of strategies for building relationships with the Internet and new media technologies of the Russian-speaking representatives of the International Dzogchen Community and the Russian-speaking communities of Theravada Buddhism. In accordance with the algorithm of Campbell's approach, in our study, we took into account the history of socio-cultural consolidation of the Dzogchen teachings and Theravada Buddhism in Russia, the impact of the practices of the Dzogchen Community and the Russian-speaking communities of Theravada on building relationships with the Internet and the media, and forms of using new media and community discourses about media technologies.

\subsection{Emergent Digital Environment of the International Dzogchen Community: If Tomorrow Has Come}

The first Dzogchen groups appeared in the early 1990s due to the visits of Chögyal Namkhai Norbu ${ }^{6}$ to St. Petersburg and Moscow. At that time, the Dzogchen groups seemed to be something fundamentally new in relation to Buddhist monasteries and datsans, well known in Russian Oriental and Buddhist studies. They did not strive for registration as reli- 
gious associations and did not try to interact with the traditional Buddhist organizations of Buryatia, Kalmykia, and Tuva. The worldview basis of this position was the interpretation of Dzogchen regional groups as structural units of the International Dzogchen Community. The International Dzogchen Community was established by Namkhai Norbu in 1981 and registered in Italy as a "cultural association". The transnational principle of its organization has a unique religious background. The organizational structure of the International Dzogchen Community reproduces a symbolic communicative code, intuitively understood by its members in all countries, where Dzogchen is spread through the Namkhai Norbu line. This code is the mandala (Buddhist cosmogram) as a graphic reproduction of the individual psyche. The International Dzogchen Community has urban small centers (lingas) in each country of its distribution. In addition, some countries have established large centers (gars) located outside the city for large teachings (retreats) and big gatherings of members of small communities.

As long ago as Namkhai Norbu first visited Russia, he entrusted his closest Russianspeaking students with a task of creating a "gar" ("settlement" in nature)—a large community center in the bosom of nature, built for large meetings in the cases of the Teacher's visits to Russia, as well as for Dzogchen practices, etc. The history of the Russian Gar is reproduced in detail in an interview with one of the instructors (born in 1964) authorized by Namkhai Norbu ${ }^{7}$, who stood at the origins of the Moscow small community (Rinchenlinga) and the Russian Gar of the International Dzogchen Community (North Kunsagar):

Namkhai Norbu Rinpoche first arrived once every 2 years, and that was 1994, 1996, 1998. The Russian Dzogchen community was actively developing, and got its adherents not only in Russia, but also Ukraine, Latvia, all countries around grouped together. So Namkhai Norbu Rinpoche decided that since more than 1000 people regularly gathered for his retreats, it was necessary to organize a place where they could meet and study. Until then, the followers gathered in apartments and workshops. In 1994 he said- "Look for a place where you can meet together and practice." It is called "gar" in Tibetan. We searched for two years, and in 1998 we managed to find this place. It was a wonderful story, how we found Kunsangar $<\ldots>$ and this place exists in Podmoskovye for 22 years. Perhaps it is one of the most active places in Russia. You can just come here. This center has opened to the world, many teachers come here, now it is not only the place for the Dzogchen Community.

The transnational way of organizing the International Dzogchen Community required non-standard management. Thus, the strategy for the use of technological innovations is largely conditioned by these aspects. In the early 1990s, the English-language group mailing list "norbunet" was already introduced for members of the Dzogchen Community, and in the late 1990s, telephone mediated broadcasts of the retreats by Namkhai Norbu were organized throughout the gars of the world on the same days and at the same time.

The previously mentioned first Russian authorized instructor, a graduate of Moscow Institute of Physics and Technology, Candidate of Sciences, in view of his professional activity, was one of the creators of the system for the first podcasts in Russia and the world. Using his professional knowledge and skills, he created the media for the transnational religious practices of the International Dzogchen Community. He described the chronology of building the relationship of the Dzogchen Community with the Internet and new media as follows:

There are several chronological stages here. When there were no computers, everything was written down by hand. As soon as computers appeared, Rinpoche said that it is necessary to digitalize the Teaching. All started with a visit of an American Jim Rashik ${ }^{8}$ to the second retreat of Namkhai Norbu Rinpoche. Jim brought me a magazine from America that contained a paper about the so-called informational super highway. You remember what the computers were like in 1994. We got talking. He was engaged in information technology. Then we 
thought for the first time that sooner or later the Teacher would give teachings on the Internet. And it had already become a reality after 5 years. The first teachings on the Internet we held in Russia, when there was still no Internet, but there was another technology. In Kunsangar, we installed a phone line. The Teacher called on the phone, he had a kind of headset. The Teaching transmitted from the forest of Podmoskovye to all the Dzogchen communities of the world. That was in 1999. In 2002, in addition to being authorized as an instructor in Venezuela, I also wrote a program for entering Tibetan text specifically for Rinpoche. It became popular among Tibetan Buddhists. I posted it on the site, and people have been using it for 20 years.

The negotiations with new media technologies of the Dzogchen Community were created in light of the history and beliefs of the International Dzogchen Community. One could become a member of the Dzogchen Community only after receiving in-person the transmission of the teachings from Namkhai Norbu. The teacher lived and worked in Italy and could not often visit the gars of other countries. Against this background, some followers dared to travel on their own in order to receive the teachings in-person from Namkhai Norbu. However, many of them could not afford it. Being aware of these difficulties, Namkhai Norbu came up with a unique initiation procedure through the involvement of new media. He recorded a videotape of the Dzogchen teaching practice and distributed it to small communities in different countries. Three times a year, each community on the same day and at the same time has a practice of "remote transmission of the Teaching". Thus, from the very first steps into the fold of the transnational Dzogchen Community, its members met with non-trivial technologies for the transmission of religious knowledge. We have heard about such a non-standard means of initiation from an interview with the second Russian-speaking authorized instructor of the International Dzogchen Community (born in 1968). For many years, he was the personal interpreter of Namkhai Norbu at retreats held for the Russian-speaking audience and retained in his memory a lot of knowledge about the digital development of the Dzogchen Community:

A remote transmission system appeared in 2000. To organize it, we used a videotape with a recording of practice. We synchronized to this cassette practicing at the same time as other communities. Chögyal Namkhai Norbu videotaped the Dzogchen transmission practice. The cassette was not distributed publicly and could be received only from the local Dzogchen communities. Three times a year we met, namely on the anniversaries of Garab Dorje, guru Padmasambhava, and Adzom Drugpa. For example, on the anniversary of Garab Dorje, we arrived at 5 a.m., put on this cassette, and have a practice in step with Chögyal Namkhai Norbu. Those who did not have the opportunity to come to the retreat by Chögyal Namkhai Norbu could participate in such a way. And in this way, new people came to the Dzogchen Community. This was like that for years, because the Internet in those days did not allow video broadcasting.

Namkhai Norbu created his own system of teaching Dzogchen, which he called "Santi Maha Sangha". It was supposed to involve four stages of successive mastering of the vast complex of Dzogchen teachings and practices. The respondents expressed their regret that the Teacher did not complete this system. He managed to develop in detail an algorithm for passing through three levels, and he provided in-person training at each of them. Followers from different countries could join the lectures and retreats by Namkhai Norbu in real time, since he used advanced technologies. The Dzogchen Community very quickly mastered telephone webcasting and soon created its own webcasts. In the early 2000s. Namkhai Norbu's son Yeshi Namkhai, being a highly professional specialist in IT technologies, created the "webcast.dzogchen.net".

The details of using these technologies were discussed in an interview with the second authorized instructor: 
Since 1999, telephone broadcasts have begun. It was like this usually. Chögyal Namkhai Norbu comes somewhere, and transmits one day of the retreat only to the gars of the Dzogchen Community of Podmoskovye, America, Argentina, etc. The Dzogchen Community's mail-out is preserved in norbu.net archives since the 1990s. I had been connecting to it through a Dutch server since 1996. It was a private mail-out, there was no other. It became official at least in the mid-1990s. It served to exchange information, and there were a lot of discussions in this mail-out. Then, in 1998, a Russian mail-out appeared. And since 2005, webcast of retreats has already begun. Chögyal Namkhai Norbu's son created this webcasting system. It's very efficient, these were connections only to gars and lings at the initial stage. It became possible for everyone to connect later. At first, we paid a lot of money to afford webcasts with minimum delay. We also used this system later, did not use Google Hangouts, because there may be a delay of one and a half minutes. And we had minimum delay, because we rented very powerful servers, first in Italy, and then in America. There were different webcasts: open webcasts, to which anyone could connect, and private broadcasts, to which only the members of the Dzogchen Community could connect using a password. But there were few closed ones, most of them were open. Those who wish could learn about them through norbu.net, people connected on their own.

According to the members of the International Dzogchen Community we interviewed, the innovative strategy in relation to media technologies was initially associated with the Weltanschauung of Chögyal Namkhai Norbu. He taught "to use those means and tools that correspond to the time period and existing tasks". Therefore, the Dzogchen Community was one of the first to use Google-group Norbunet, and then its Russian-language analog Voice, for quick communication, information, and solution of organizational issues. After the death of the Teacher, the International Dzogchen Community has used the system for online broadcasting of retreats and teachings on the website "webcast.dzogchen.net", created in the early 2000s by Namkhai Norbu's son. The history of the transnational community in a variety of events, teachings, meetings, and specific practices was reflected for several decades in the "Zerkalo" newspaper. First, it had a paper format, then it was digitized, and a separate website was created for its materials. The respondents sent links to this site, as a rule, in response to the questions about certain concepts or local events of a particular year.

The existence of the International Dzogchen Community after the passing of its Teacher was a very delicate subject for the respondents. Here, we would like to cite an excerpt from an interview with a young Russian-speaking member of the Dzogchen Community (born in 1985). His answer is interesting in several aspects. Firstly, having an economic education and extensive experience in digital marketing and web development, he explained how the media infrastructure of the Dzogchen Community works in its current form. Secondly, he shed light on the specifics of its activity on social networks:

We are currently using website "webcast.dzogchen.net" to transmit recordings of the teachings by Namkhai Norbu and to webcast practices. This allows members of the Dzogchen Community from different parts of the earth to practice simultaneously in real time. The website has an archive of materials, but it is small. A full-fledged large archive is now in the process of indexing materials and developing software for accessing materials. The Shang Shung Foundation and Merigar West (the center of the Dzogchen Community in Italy) seized this matter. From time to time, we show recordings with Namkhai Norbu. There is an open section with open webcasts on our website, as well as a section with private ones, which the Teacher designated as private. It is determined by the nature of the teaching-something can be given publicly, and something not. In social networks, we are represented on Facebook-there are Facebook groups of large and small centers, a Facebook group "Zerkalo". There are groups that publish information about open events related to Yantra Yoga, Santi Maha Sangha, and 
Kaita (festal dances and songs). There are few of us on vk.com, because the Russian-speaking Dzogchen Community uses primarily Google groups, email, and instant messengers to communicate with each other. This was determined by history. There are online practices, when we learn from instructors. They answer the questions concerning practice at Zoom or Google meet. Shared practices are also held online. For example, we have practices in accordance with the lunar calendar; they are held four times a month - on the 10th, 15th, 25th, and 30th. These are practices of feast offerings called Ganapujas. The practices themselves take place offline-a person performs the practice in the ling or in the gar (rarely at home), as a rule, with other practitioners there. And webcasting allows practitioners from other places to join to the practice.

Our guide included a question about the possibility of digitalizing all the practices of the Dzogchen Community. In the course of the interview, it turned out that both open and private practices (those that require transmission and special initiation) are held online. However, the very initiation and transmission of secret practices in the Dzogchen Community can be carried out only offline in the process of teacher-student communication.

\subsection{Invincible Sun of the Russian-Speaking Theravada: A Single Digital Niche Versus Offline Competition of Communities}

Russian-speaking Theravada communities presenting themselves in groups on vk.com and their own websites are a relatively new phenomenon. In the early 1990s, there were only a small number of active Theravadins among the Russian convert Buddhists. They learned about Theravada from books and organized rare short-term visits to Russia for foreign Western and Asian teachers. The result of such visits was the registration in 1992 of two Theravada organizations-Bodhimandala and Patibodhana. However, they had not existed for a long time. The visits of foreign teachers subsided, and there was no coherence of practices and further community strategies in the Theravada Russian-speaking environment $^{9}$. There were no resident monks or masters of Theravada tradition to explain the principles of the organization of life in the community. Therefore, the Russian-speaking Theravadins focused on translating the books of individual Asian and Western Theravada teachers from English. Significant shifts towards the development of communities began only in the 2000s as a result of two circumstances. Firstly, some followers traveled to the countries of Southeast Asia to train and ordain as bhikkhu/bhikkhuni or to receive experience in Buddhist communities or meditation centers. Upon returning to Russia, some of them established new communities of the Theravada tradition they learned in Asian monasteries. Secondly, the spread of the Internet and social media created a truly unprecedented opportunity to study dharma online. The Russian-speaking Theravadins opened a separate niche within the Buddhist Forum website developed in 1998 to hold their discussions and then created their own websites. The current Russian adherents of Theravada Buddhism are represented by small autonomous communities that use the Internet and new media technologies to spread and popularize the Theravada Buddhist traditions.

Almost every interview about the Buddhist media spaces invariably began with a discussion of the lack of integration among the Russian-speaking Theravada communities. Respondents emphasized that each community strives to create its own digital niche. Here is an example from an interview with a St. Petersburg Buddhist Theravadin (born 1975), a historian, creator of a popular Facebook public page and a group on vk.com. He witnessed the arrival of most of the teachers in Russia and the creation of communities and is well acquainted with the heads of many communities of the Russian-speaking Theravada. He received lay vows from His Holiness the 14th Dalai Lama, and he later gained the experience of monastic life in the monasteries of Myanmar. In an interview, the respondent gave a detailed description of Theravada communities and outlined a map of their digital activity: 
The Russian-speaking Theravada is a complex phenomenon. First of all, there are many communities and groups, spiritual aspirants who have no desire to unite, because they have different teachers and traditions. Sometimes they come across each other at retreats, but this rarely happens. Spiritual aspirants create their separate websites and forums. They hold on to their views, peculiar understandings of theory, and practice; they create their own closed communities. They comprehended Buddhist teachings from books and their own translations, discussed difficult issues on forums. In 2002, Kyiv Buddhists created a wonderful website dhamma.ru and a related forum. Around the same time, the "Buddhist Forum" became popular, where various issues of theory and practice were discussed. After several years, the Buddhavihara community in Gorelovo was merged into St. Petersburg community, and after some time, the backbone of the community left Buddhavihara and created its independent community headed by the Russian native-born monk Bhante Pannyavudho (Topper). Since about 2007 , the St. Petersburg Theravada community has had its own website, which is constantly updated with new translations http:/ / www.theravada.ru (accessed on 15 April 2021). On the vk.com social network, it is represented by groups of the same name located in various regions of Russia. The Buddayana.ru group is in close cooperation with website "theravada.ru". By the way, it also has its own website https: / / theravada.world (accessed on 15 April 2021). The Theravada.ru community sought to develop its Facebook groups, but they failed to find their audience. It was not possible to achieve such popularity as on vk.com. In 2011, if I am not mistaken, the Theravada community appeared in Moscow. It also has its own website "https: / / www.theravada.su/ (accessed on 15 April 2021)." and groups on Facebook and VK known as Theravada Buddhism in Moscow. They usually hold their meetings in the Rime center. Around the same time, a group of adherents of the Thai forest tradition was created in Moscow on the basis of the Korean center Dalmas (dalma.ru). They have set up their own website with translations, "http:/ / forestsangha.ru (accessed on 15 April 2021).", in 2013, and now regularly invite Buddhist teachers to Russia for retreats.

He assesses his blogging activity on the Facebook public page and on the VK group as popularizing, aimed at attracting a wide audience. Not belonging to any of the Russianspeaking communities, keeping aloof from their confrontation, he saw his mission in transmitting teachers' reflections on doctrine and distribution of Russian translations of the canon texts and commentaries. Actually, acting as a theoblogian, he himself chooses topics for coverage and teachers for online promotion and writes his own educational articles:

My activity on the public pages is of interest and importance to me, because there I can share with readers something that I find inspiring, interesting, and useful for myself. These may be biographies of prominent Theravada monks of the past or present, my translations of instructions on practice or theory, and even some kind of culturological, cultural, and educational material, for example, about Buddhist archaeological sacred monuments. I share information about the release of important Theravada books and new translations or upcoming retreats. My target audience is Buddhists, sympathizers, spiritual aspirants of any traditions; if something has seemed interesting and useful to them, then it's already good.

Interviews with the developers and administrators of the websites mentioned above showed that the dominant activity of the Russian Theravada groups is independent translations of the Pāli Canon. The respondents emphasized that Theravada Buddhism is a fundamentally new tradition for the Russian socio-cultural context, previously known to a narrow circle of professional Buddhist scholars. In view of this, they consider the digitalization of translations, online publication of materials about Russian-speaking Theravadins, and discussion of doctrine and practice on forums as means to popularize Theravada Buddhism in Russia. 
Here is the example of a respondent (born in 1984) ${ }^{10}$, a lawyer and a creator of his own website "theravada.world". He represents a "digital spokesperson", since his online activity expresses the interests of a particular community. In an interview, he noted that "theravada.ru" was the first website to appear within the space of the Russian Internet. The inspiration came from the head of the St. Petersburg Theravada community, the monk Topper, and the developer of this site was a man under a working pseudonym SV. According to the respondent, the Theravada tradition has become famous in Russia outright thanks to the website "theravada.ru" and its digital representation through the website "theravada.world". Moreover, he underlined that the content of these sites is a source of inspiration for the Russian post-modernist fiction writer Viktor Pelevin ${ }^{11}$ :

The word "Theravada" was not used about 20 years ago. In relation to Southern Buddhism, it was common to speak of "Hinayana". When the Internet appeared, Theravada was still not a search relevant term. On the Russian-language Internet, all the information concerned the Mahayana. It went on for a long time before the first site with the corresponding name "Theravada.ru" was set up. The translations of the Sutta-Pitaka were posted there every day for 10 years. Thanks to this, many people in Russia heard about Theravada. This is evidenced by the fact that Pelevin's last book ${ }^{12}$ is no longer devoted to Mahayana, or Zen. We can see that he describes practice of Theravada, and it's obvious that he learned it through the materials available on our website. And he, willing or not, became a mouthpiece for another level of Theravada. In 2019, I initiated theravada.world website, because over the past 10 years, Theravada Buddhism has become known, and there are a lot of those who are interested in it. People have learned that there is an alternative to Mahayana Buddhism. I got an idea how to organize these people based on their enthusiasm. And do something together. So, the idea of online community has arisen. The idea was to create a website with open architecture where everyone can share texts, photos, translations, as well as perform changes to its content. It can be a kind of encyclopedia, which is replenished by readers. I thought that it would be good if the seeker had such an online resource where everything was collected. I aimed to make something akin to Wikipedia, a reference resource.

It should be emphasized that the translation of the texts of the Pāli Canon into Russian and their popularization through websites is interpreted by the respondents as an independent religious practice. The co-founder of the Moscow Theravada community, who created the theravada.su and tipitaka.theravada.su websites, speaks about this in his interview. Having a specialized technological education, he himself wrote the software for these sites and considers them as a resource for members of the Moscow community and all those who want to devote themselves to the "Theravada tradition based on the Pâli originals":

I got interested in Buddhism in the late 1990s, and in the 2000s I chose the Theravada tradition and started translating some texts. Initially, my works were published on other sites, later I myself mastered the technology of their development. I have an IT education that allowed me to develop software for both sites. I launched the theravada.su website in 2007, and later, in 2011, I re-registered it on another domain. In 2009, together with the Russian-speaking monk Buddhanyano Bhikkhu (Raudex) ${ }^{13}$, we created a Buddhist community in Moscow called "Theravada Buddhism in Moscow". There is also the "Theravada Buddhist Community", officially registered in Balashikha near Moscow, but we held practice in Moscow. Now I have two websites-theravada.su and tipitaka.theravada.su, both made by me. Over time, it became clear that lectures were needed there. Since then, my work has been aimed at researching important texts and terms and preparing lectures for the community. Software development is on me. The platform of the site "www.theravada.su" (accessed on 15 April 2021) is an open content management system "Drupal" (https:/ / www.drupal.org 
accessed on 15 April 2021). The "tipitaka" website was developed around 2015; initially, there were only Pāli texts, then I made it possible to add translations as well. I continue to refine the tipitaka software, and the members of our community download new material on the site. Website development and translation is also a religious practice. It continues the tradition that in ancient times began with the oral transmission of teachings, then Buddhist books were published, and now the websites are developing.

As follows from the interview, the above-mentioned respondent implements the strategy of a "digital professional" seeking to use his skills on behalf of his Theravada community. He describes his own work on translation of texts from Pāli canon and its further digital promotion the respondent describes as a form of religious practice. He sees his religious mission in the digital delivery of undistorted texts, as he translates them himself, relying on the Pāli originals, and posts them on his websites. The respondent believes that this allows followers to get acquainted with an authentic version of the methods of Buddhist initiation and daily practice. Based on his translations of the Pāli texts, he argues that a layperson does not need a monastic sangha or a monk to take refuge, and lay people can assume the role of interpreters of the Buddha's Word without competent monks:

I am a layman. For the laity, the practice of charity is especially prominent, it involves donating, supporting Buddhist monks, etc. Any charity is a blessing, it creates the preconditions for well-being. In addition, the lay Buddhists are recommended to observe 5 principles, the lay people can also engage in meditation - the development of the mind by means of the techniques that the Buddha gives in the texts and which are explained in detail in the commentary literature. These practices online be an instrument of studying and discussing Buddhist texts, giving financial support for communities, centers and monks. In theory, the translation and commenting on the texts should be made by monks with a Buddhist education. At the moment, none of them is engaged in this work, so lay people do it. In addition, there is disagreement among the Russianspeaking followers of Theravada Buddhism about taking refuge in the Three Jewels. Some of them argue that refuge is given by a monk and cannot be taken without assistance. I have criticized this point of view, pointing out that it has no basis in the canon. As a result of researching this issue, I co-authored the article that caused a stir.

In 2018, an attempt was made to combine the efforts of various Theravada digital resources within the framework of the newly emerged website Theravada.rf. Its developer was a well-known Buddhist Theravadin (born in 1981), who began his spiritual path with mastering the Vipassana method as interpreted by Sri Satya Narayan Goenka. He devoted many years to studying various practices of working with consciousness, later came to Buddhism, lived for 6 years as a monk in one of the Theravada monasteries in Sri Lanka. Upon his return, he sought to unite the conflicting Russian-speaking Theravada in the online space through a common website where everyone could upload their translations, articles, etc. Having failed in the implementation of his original plan, he was forced to take on the strategy of 'theoblogian' by posting translations of texts, his own stories about meditation practices, teachers, monasteries, Russian-speaking monks and nuns on his website:

In 2005 I became an active member of the Vipasana group, it does not require any religious affiliation. And by the way, if you've read a new novel by Pelevin "Invincible Sun," you probably noticed that he writes about Vipassana, and also mentions Goenka. I was an active member of Goenka Vipassana group for a long time. Then I decided to leave in India for a year. At that time, I had realized that want to join a Buddhist monastery. I went to the Theravada monastery in Sri Lanka, and took first probationary vows and then monastic vows. During 
that period, I wrote a book under my monastic name Alokananda "Anthology of the Buddha's Teachings." Later, it spread over the Internet. When I returned to Russia 6 years later, I already knew about the Russian Theravada communities. But it was difficult to find common ground with them, I have left the Theravadin Buddhist forums many times. My wife and I created a group called "Realizers of the Russian Federation's Fantasy" in Vk.com and Fb. I added "the RF" because I wanted something good for my country. But the group entered into discussions of spiritual searches, and then became completely Buddhist. I began to write about meditation, about various meditation techniques, stories from the monastery, from the life of Buddha. I translated several books describing the techniques of various teachers in this tradition. I thought about where to post this material. It turned out that each Theravada resource is a presentation of a certain group and its views. And these groups are at enmity with each other, there are several types of such splits. Even if you have not joined any group, you in any case belong to a certain Theravada tradition, and there are many of them. My wife and I made playing cards game "Clarity Cards" 14 and a corresponding mobile application for Android, which we put in Google Play. The idea was born to make a portal that would unite everyone, so that all the articles and translations related to Theravada would be there. In 2018, my friend, a webmaster, made a site for me, and my wife developed its design. I invited people interested in Theravada Buddhism to give materials. But no one really responded. I look through all the materials about Theravada on the net, copy and post information about Russianspeaking monks and nuns. I don't have any attendance registration on my site, no forums where everyone wrangles, I don't compete with anyone. The result of my spiritual practice I post on my website.

In each interview, the respondents raised an issue of competition between websites, expressing some criticism towards each other. The subject of criticism is not the technical characteristics of the sites, their style or content. The basic causes of the confrontation between the Buddhist digital creatives are the approaches to translations of the texts from the Pāli Canon and the ways of building a religious community. All the respondents emphasized that the Buddhist translations published in Russian are fragmentary, and therefore they have to translate by their own. In the absence of a monastic sangha permanently living in Russia, the laity organize themselves, solving at their own peril and risk the issues of newcomers' initiation, strict observance of religious precepts, and authenticity of their religious conduct in accordance with Theravada tradition. In this context, they regard translations and commenting as the only possible way to gain knowledge straight from the source and to establish the authenticity. They also described their digital work as a religious practice.

\section{Conclusions}

Russian-speaking digital Buddhism is a heterogeneous reality in which online communities, sites, webcasts, public pages in social media developed or used by offline Buddhist organizations coexist with online communities of so-called online Buddhists. We argue that digital mapping of this reality should be carried out not analytically, as foreign colleagues suggest, but by means of quantitative benchmark survey. Mathematical model approach allowed us to create a digital map of the Buddhist online communities on the Vk.com social network. We found that the "Buddhist niche" of the Vk.com social network is represented by online communities of the followers of offline Russophone Buddhism, and by various quasi-Buddhist communities that have no offline alternatives. Buryat, Kalmyk and Tuvan online communities of the Gelugpa school and the online group of the Russian Association of Communities as part of the Karma Kagyu International Organization, prevail in terms of quantity and their online activity. The number of online communities of the Russian-speaking part of the International Dzogchen Community and the Theravada is considerably less. In addition, there are precious few Dzogchen communities on the 
Vk.com network and they are predominantly private. The Russian-speaking Theravada groups are not consolidated. Comparison of the results obtained for Vk.com with data on online communities, public pages and groups on the Fb.com showed that the digital activity of the Russian-speaking Buddhist organizations in these social media is different. In the Buddhist niche of the $\mathrm{Fb}$.com platform personal blogging accounts of members of the Dzogchen Community and the Russian-speaking Theravada prevail. We supposed that digital mapping of Buddhist online communities, public pages, and blogs on Fb.com, combined with a qualitative study of this environment, can shed light on the peculiarities of building relationships with the Internet and new media by traditional Gelug ethnic offline organizations and the Russian branch of the International Karma Kagyu Community.

Digital mapping of the Buddhist niche in Vk.com has revealed a significant gap in knowledge about the online profiles of the Russian-speaking part of the International Dzogchen Community and Theravada. The next study phase made it possible to identify the media used and the types of Buddhist digital creatives, whose efforts worked towards shaping of media technologies.

Chögyal Namkhai Norbu's strategy for dealing with the Internet and new media technologies has resulted in the construction of digital environment of the International Dzogchen Community. It was shaped thanks to the efforts of "digital professionals" Namkhai Norbu himself, his son, a professionally educated IT technologist, and Russianspeaking followers. The International Dzogchen Community was initially developed as transnational, i.e., it wasn't associated with a specific territory, center, country, or ethnicity, etc. Media created by community digital professionals— the Norbunet mailing list, the online newspaper "Mirror", and the website "webcast.dzogchen.net." for live web streaming - were essential for the digital presentation of the International Dzogchen Community. The low demand for vk.com is explained by the fact that this social media is focused mainly on Russian users. The Russian-speaking members of the International Dzogchen Community are aimed at translocal communication within their own digital environment. However, the use of Facebook.com and YouTube is an additional resource for covering public events, as well as for holding local private meetings and keeping closed groups.

The innovative strategy of the Russian-speaking Theravada was developed in a completely different way. In this case, a positive attitude towards the Internet and new media technologies is associated with the desire to popularize Theravada Buddhism in Russia. Innovation here is mediated by intercommunal offline competition for the authenticity of the authority and tradition transmission. The social organization of the Theravada community should include a monastery and monks. How to reproduce Theravada Buddhism outside this traditional structure is one of the key challenges faced by Europeans and Russians wishing to practice Theravada in their homeland. The discovered online confrontation between Theravada websites mirrors the competition between offline Theravada communities of various teaching traditions. This competition has motivated digital strategists and spokespersons of the Russian-speaking Theravada to develop their own websites and open online communities on the vk.com social media. Here, we can talk about the reverse influence of the media on a specific religious environment. Digital spokespersons, 'theoblogians', and professionals of Theravada communities closely monitor changes in the online infrastructure of the Russian-speaking Theravada, look through discussions on website forums, in Telegram chats, on personal public pages, blogs, as well as in groups on vk.com and Facebook. The leading online religious practice in this niche is the popularization of Theravada Buddhism through translations of the Pāli Canon into Russian, commenting on its texts, stories about Asian and Western teachers, and discussion of practices and techniques on site forums. Theravada digital creatives strive to shape a similar media content-websites with translations of canon texts, forums, public pages, and social media groups. The Internet has become an acceptable place where Theravada websites unintentionally compete with each other's work, in a division between those relying merely upon the outreach vision of Theravada and those devoted to internal community use. In many 
ways, these websites serve as the face of the Russian-speaking Theravada, as well as a social landscape in which to communicate through user participation.

Author Contributions: Conceptualization, E.O. and T.B.; methodology, E.O. and T.B.; software, F.K.; validation, E.O., I.A., and T.B.; formal analysis, F.K.; investigation, E.O., I.A., and T.B.; writingoriginal draft preparation, E.O. and T.B.; visualization, F.K.; project administration, T.B.; funding acquisition, T.B. All authors have read and agreed to the published version of the manuscript.

Funding: This paper was prepared with the financial support of the Russian Foundation for Basic Research, grant No. 20-011-00531 "Russian Buddhism and Social Media: Digital Transformation of Buddhist Communities".

Informed Consent Statement: Informed consent was obtained from all subjects involved in the study.

Data Availability Statement: The data presented in this study are available on request from the corresponding author. The data are not publicly available in order to assure anonymity and privacy of the participants.

Conflicts of Interest: The authors declare no conflict of interest.

\section{Notes}

1 In 1994, Gary Ray first coined the term "cybersangha" to describe the Buddhist community online. In 2004, the American Buddhologist Charles Prebisch suggested using this term for denotation of various sites of traditional Buddhist communities, the virtual temples they create, Buddhist online groups that have no offline alternative, and Buddhist online magazines. Prebisch's proposal had no methodological rationale, and, in essence, was a kind of manifesto of the academic scholar who openly declared his affiliation to Buddhism and desired a conflict-free online unification of various Buddhist traditions, communities, journals, and Buddhologists (Prebish 2004). Sangha is a Sanskrit word meaning "association" or "community". It has two levels of meaning: the ideal level of "Arya-Sangha" denotes all of the Buddha's disciples who have attained the level of Arya on the noble eightfold path from srotapanna to Buddha. In this meaning, Sangha is the third component of the Three Refuges in Buddhism.On the conventional level in Mahayana Buddhism, it is referring to four-parted sangha: the monastic community of monks (bhikkhu) and nuns (bhikkhuni), and laycommunity of laymen (upasaka) and laywomen (upasika). In the Theravada School, sangha does not include lay followers, but the monastic community of ordained followers only.

2 The initial version of Helland's concept was developed in 1999 and based on the analysis of Christian, Jewish, and Buddhist sites randomly selected by the Yahoo search engine. The proposed distinction between "online religion" and "religion online" was intended to show the difference between the new digital religion as a kind of online religious participation from non-interactive information resources, websites, and libraries of the "old" religious tradition. Under the pressure of academic criticism, Helland significantly reworked his concept to clarify the phrase "online religion". In 2005, he proposed to distinguish "online religion" by its infrastructure, which includes "academic online institutions" that study a particular religion; sites of organized religions and new religions, religious forums, cyber-rituals, private publications, and religious digital magazines (Helland 2005, pp. 4-12).

3 In the article, we use the term 'Russian-speaking Buddhist' instead of 'Russian Buddhist' or 'Buddhism in Russia' for two reasons. The first one is the transcultural and translocal context of media communications, which are not attached to a place or country. Buddhists of same tradition/organization living in different countries use the Internet and new media technologies to be involved in translocal community life, practice, or obtain the teachings. They can affiliate themselves with different traditions or communities but meet on the Russian-speaking Buddhist forums and platforms, and discuss issues on websites. The second reason is that the Buddhist communities and organizations of Russia do not fit into any of the typical categories for identifying Buddhists in the West (Prebish 1999; Tweed 2002; Harding et al. 2010). In the Russian academic field of Buddhist studies, it is customary to distinguish between the so-called traditional Buddhism of Buryatia, Kalmykia, and Tuva and the Buddhist convert communities (Ostrovskaya 2004). These two terms were introduced in 1990s as an attempt to analyze a Buddhist restoration in Russia after the fall of USSR. During last thirty years, the socio-cultural context of the religious situation drastically changed. The processes of globalization and mediatization brought the hybrid organizational forms of religious practice and communication, as well as previously unknown forms of cybercommunities. Additionally, there is a minor linguistic aspect that could be misunderstood in English because of the meanings of the word "Russian". The main one is "ethnically Russian", "Russkiy", but the second is more linked to supra-ethnic national "All-Russian", "Rossiskiy".

4 Thus, according to the Federal State Statistics Service, 269 Buddhist religious organizations were registered in the Russian Federation in 2018 ( 2019, p. 177).

5 The word "Zen" in Russian often has two variants, “Дзен" and "Дзэн". The first one is probably more accurate according to the Russian language rules for foreign words adoption. The second option is used in accordance with the rules for the transcription of Japanese hieroglyphs. It is also highly likely that it is more concerning non-Buddhist mass culture meanings and economic activities like Zen-Pizza (Дзен-Пицца) or Yandex Zen (Яндекс Дзен). This difference is reflected with search results 7 and 9 when one can find 113 Дзэн/Zen and 974 Дзен/Zen VK communities. Obviously, the majority of these Дзен/Zen groups have very weak links to Zen Buddhism, but their content refers to popular culture images within some Japanese or East Asian elements. 
6 Chögyal Namkhai Norbu is a well-known scholar in the Western Buddhist world who for a long time taught Tibetan and Mongolian languages and literature at the University of Naples and advised Giuseppe Tucci himself. In the 1960s, he began teaching the spiritual practices of the Dzogchen to his students and found a large number of disciples and followers in Italy and abroad. Namkhai Norbu was the founder of three large organizations-the International Dzogchen Community (1981), the non-governmental organization "Association for International Solidarity in Asia" (1988), which put forwards education and health care in Tibet, and the Shang Shung Foundation for the Preservation of the Tibetan Cultural and Religious Heritage (1989). It is very important to take these activities of Namkhai Norbu into account, since we can comprehend the extraordinary scope of his contribution to the preservation and reproduction of Tibetan culture and religions. Throughout his life, Namkhai Norbu maintained close relationships with the Tibetan diaspora and its spiritual leader, His Holiness the Dalai Lama.

7 Chögyal Namkhai Norbu authorized two Russian-speaking instructors to teach the Santi Mahasangha system to members of the International Dzogchen Community (from expert interviews with these instructors).

8 Jim Raschick-http://melong.com/passages-died-jim-raschick/ (accessed on 15 April 2021).

9 The Russian-speaking Theravada communities have not been subjected to sociological research. We found a discussion of the main milestones in the development of the Russian-speaking Theravada with some dates and names on the forum of the Ukrainian site "dhamma.ru". In 2017, the site celebrated its 10th anniversary; in this context, the history of Theravada Russian-speaking Buddhism was discussed. See: https:/ / dhamma.ru/forum/index.php?topic=687.0 (accessed on 15 April 2021).

10 He identified himself as “a lay Buddhist of the Theravada (Buddhayana) tradition (southern Pali Buddhism), an active Buddhist and Kulturträger. He took his first Buddhist Refuge more than 12 years ago.

11 Viktor Pelevin (born 1962, Moscow, Russia, U.S.S.R.), is a famous Russian writer, the author of "Chapaev and Void", "Omon Ra", and "Generation $\mathrm{P}$ ", whose novels, often reminiscent of fantasy or science fiction, depicted the grotesqueries and absurdities of contemporary Russian life. Pelevin was a reclusive man who practiced Buddhist meditation as a way of withdrawing from the chaos of the life around him. Not only were his works wildly popular with young Russian readers, but they also were highly regarded in the non-Russian literary world, which saw in them as a continuation of the tradition of Russian protest literature. See more on https:/ / www.britannica.com/biography/Viktor-Pelevin (accessed on 15 April 2021).

12 The respondent meant the book "Invincible Sun" by Viktor Pelevin. It was published in Russian in 2020. A protagonist of the novel is the young woman who in honour of her thirtieth birthday goes to travel in search of herself. She visits Turkey and Cuba, in ancient temples, and witnesses the sunset and sunrise of Sol Invictus (invincible sun), which is the last pre-Christian deity of the Roman Empire.

13 Buddhanyano Bhikkhu (Raudex) is the native-born Russian taking his monastic vows in 2013 at Wat Ban Suan in Thailand.

14 The card game for 4-6 players, in which all players fight for their own in order to gain eight cards with the Buddhist qualities of a Pure Mind. The respondent explained that the game was in use only whithin a narrow circule of friends. Its digital promotion as an app failed because of lack of financial and technical support. Digital version of the game is still available online in the vk.com group "Realizers of the Russian Federation's Fantasy".

\section{References}

Aktamov, Innokentiy G., Timur B. Badmatsyrenov, and Nikolay V. Tsyrempilov. 2015. Buddhism in Russia in the Internet Dimension. Vlast 7: 125-30. Available online: https://www.jour.fnisc.ru/index.php/vlast/article/view/5674 (accessed on 17 April 2021).

Aktamov, Innokentiy G., Timur B. Badmatsyrenov, and Fedor V. Khandarov. 2018. The Peculiarities of the Virtual Buddhist Communities Development in the Runet. Vlast 2: 100-5. Available online: https://www.jour.fnisc.ru/index.php/vlast/article/view/1469 (accessed on 17 April 2021).

Anderson, Jon W. 1999. The Internet and Islam's new interpreters. In New Media in the Muslim World: The Emerging Public Sphere. Edited by Dale F. Eickleman and Jon W. Anderson. Bloomington: Indiana University Press, pp. 41-55.

Badmatsyrenov, Timur B., Maxim V. Skvortsov, and Fedor V. Khandarov. 2018. Topological Characteristics of the Buddhist Community in the VKontakte Social network. Sociological Studies 8: 74-82. [CrossRef]

Campbell, Heidi A. 2010. When Religion Meets Media. London: Routledge.

Campbell, Heidi A. 2013. Introduction: The rise of the study of digital religion. In Digital Religion. Understanding Religious Practice in New Media Worlds. Edited by Heidi A. Campbell. New York: Routledge, p. 13.

Campbell, Heidi A. 2016. Framing the Human-Technology Relationship: How Religious Digital Creatives Engage Posthuman Narratives. Social Compass 63: 302-18. [CrossRef]

Cheong, Pauline H., Shirlena Huang, and Jessi Poon. 2011. Cultivating Online and Offline Pathways to Enlightenment. Religious authority and strategic arbitration in wired Buddhist organization. Information, Communication E Society 14: 1160. [CrossRef]

Connelly, Louise. 2015. Toward a Typology and Mapping of the Buddhist Cyberspace. In Buddhism, the Internet, and Digital Media: The Pixel in the Lotus. Edited by Gregory P. Grieve and Daniel Veidlinger. New York: Routledge, pp. 59-60.

Dondukov, Bato Ts. 2017. Several Approaches to the Typology of the Buddhist Segment of the Internet. In Media Philosophy XIII. The Universe of Digital Mind: New Territories of Meaning. Edited by Valerii V. Savchuk. Saint Petersburg: St. Petersburg Philosophical Society, pp. 191-98.

Dondukov, B. Ts. 2019. Features of the Formation of the Buddhist Internet Landscape in Runet. Tver State University Vestnik. Series: Philosophy 4: 134-38. Available online: http:/ / eprints.tversu.ru/9186/ (accessed on 17 April 2021). (In Russian). 
Dorzhigushaeva, Oyuna, and Bato Dondukov. 2016. The Impact of Information Technologies on the Development of Buddhist Communities in Russia. Belgorod State University Scientific Bulletin. Philosophy Sociology Law 3: 110-114.

Falcone, Jessica. 2015. Our Virtual Materials the Substance of Buddhist Holy Objects in a Virtual World. In Buddhism, the Internet, and Digital Media: The Pixel in the Lotus. Edited by Gregory P. Grieve and Daniel Veidlinger. New York: Routledge, pp. 174-75.

Grieve, Gregory P. 2015. The Middle Way Method: A Buddhist-Informed Ethnography of the Virtual World of Second Life. In Buddhism, the Internet, and Digital Media: The Pixel in the Lotus. Edited by Gregory P. Grieve and Daniel Veidlinger. New York: Routledge, p. 25.

Harding, John S., Viktor S. Hori, and Alexander Soucy, eds. 2010. Wild Geese: Buddhism in Canada. Montreal: McGill-Queen's University Press.

Helland, Christopher. 2005. Online Religion as Lived Religion: Methodological Issues in the Study of Religious Participation on the Internet. Heidelberg Journal of Religions on the Internet 1: 4-12. [CrossRef]

Martynov, Nikita N., Olga V. Khandarova, and Fedor V. Khandarov. 2018. Graph Clustering Based on Modularity Variation Estimations. Bulletin of Irkutsk State University. Series: Mathematics 25: 63-78. [CrossRef]

Ostrovskaya, Elena A. 2004. Buddhism in Saint-Petersburg. Journal of Global Buddhism 5: 19-65.

Ostrowski, Allison. 2015. American Cybersangha: Building a Community or Providing a Buddhist Bulletin Board? In Buddhism, the Internet, and Digital Media: The Pixel in the Lotus. Edited by Gregory P. Grieve and Daniel Veidlinger. New York: Routledge, pp. 191-203.

Prebish, Charles S. 1999. Luminous Passage: The Practice and Study of Buddhism in America. Berkeley: University of California Press.

Prebish, Charles S. 2004. The Cybersangha: Buddhism on the Internet. In Religion Online: Finding Faith on the Internet. Edited by Lorne L. Dawson and Douglas E. Cowan. New York and London: Routledge, pp. 135-50.

Russia in Figures. 2019. Moscow: Rosstat.

Tweed, Thomas A. 2002. Who is a Buddhist? Night-Stand Buddhist and Other Creatures. In Westward Dharma: Buddhism Beyond Asia. Edited by Charles S. Prebish and Martin Baumann. Berkeley: University of California Press, pp. 17-33.

Veidlinger, Daniel. 2015. Introduction. In Buddhism, the Internet, and Digital Media: The Pixel in the Lotus. Edited by Gregory P. Grieve and Daniel Veidlinger. New York: Routledge. 